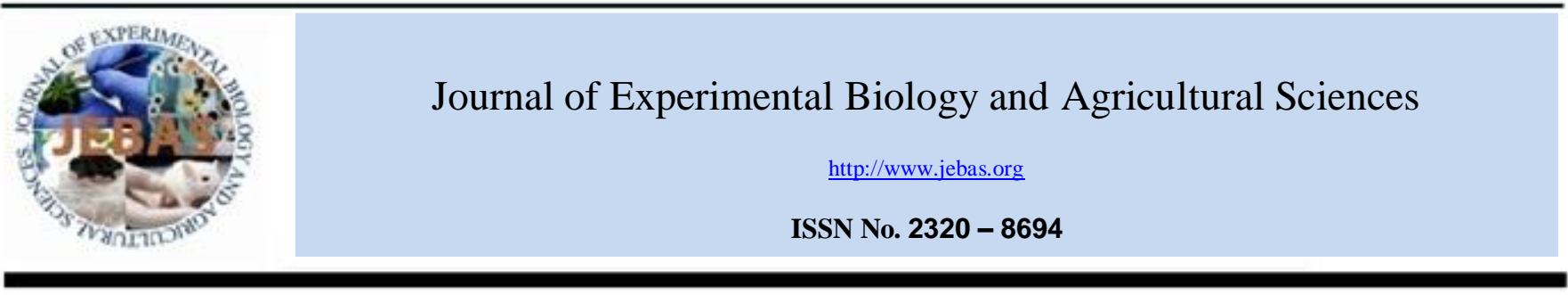

\title{
SOMATIC EMBRYOGENESIS AND CALLUS PROLIFERATION IN Picrorhiza kurroa ROYLE ex. BENTH
}

\section{Ritu Mahajan*, Nisha Kapoor and Iqbal Singh}

School of Biotechnology, University of Jammu, Jammu (J\&K) India

Received - February 19, 2016; Revision - March 17, 2016; Accepted - April 21, 2016

Available Online - April 25, 2016

DOI: http://dx.doi.org/10.18006/2016.4(2).201.209

\begin{abstract}
KEYWORDS
Picrorhiza kurroa

In vitro

Endangered

Callus

Somatic embryos

ABSTRACT

Picrorhiza kurroa Royle ex. Benth is an endangered and important medicinal plant of alpine Himalayas. Developing an efficient protocol for its mass multiplication is essential to meet the requirements of pharmaceutical industries and also in conservation of this plant under its natural habitat. Present study was undertaken to develop a protocol for in vitro mass multiplication of P. kurroa. Result of study revealed that highest frequency of shoot regeneration was achieved on Murashige and Skoog's basal medium supplemented with $1.0 \mathrm{mg} / 1 \mathrm{BAP}, 0.5 \mathrm{mg} / \mathrm{Kn}$ and $1.0 \mathrm{mg} / 1 \mathrm{GA}_{3}$, while the best rooting was observed in MS medium supplemented with $2.5 \mathrm{mg} / \mathrm{l} \mathrm{IBA}$. MS medium supplemented with $3.0 \mathrm{mg} / \mathrm{l}$ 2,4-D resulted in highest frequency of embryogenic callus. Callus inoculated on MS media supplemented with BAP and IAA resulted in both shoot and root formation while the callus on MS media supplemented with NAA and IBA resulted only root formation. The somatic embryos were established from callus on MS medium supplemented $2.5 \mathrm{mg} / \mathrm{l} 2,4-\mathrm{D}$ after four weeks. MS medium containing $1.0 \mathrm{mg} / \mathrm{l} \mathrm{BAP}$ and $1.0 \mathrm{mg} / \mathrm{l} \mathrm{GA} 3$ resulted into shoots from well developed somatic embryos. This protocol will provide a system for the germplasm conservation in P. kurroa by multiplication and regeneration of true to type plants.
\end{abstract}

* Corresponding author

E-mail: ritufeb@gmail.com (Ritu Mahajan)

Peer review under responsibility of Journal of Experimental Biology and Agricultural Sciences.

Production and Hosting by Horizon Publisher India [HPI] (http://www.horizonpublisherindia.in/)

All rights reserved.
All the article published by Journal of Experimental Biology and Agricultural Sciences is licensed under a Creative Commons Attribution-NonCommercial 4.0 International License Based on a work at www.jebas.org.

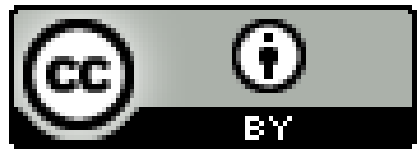




\section{Introduction}

The increasing demand of medicinal plants for the development of several drugs and chemotherapeutics has threatened their natural habitats and now they are in brink of extinction (Mugula et al., 2012; Bodeker et al., 2013). These plants are demanding to be conserved for their potential utility. One of such plant is Picrorhiza kurroa Royle ex. Benth belonging to family Scrophulariaceae which is endemic to Himalayan region (Patial et al., 2012). The plant grows from Kashmir to Sikkim at an altitude of 3,000-5,000 meters. The rhizomes of the plant are the principle source of iridoid glycosides out of which the major is Picrosides and kutkosides (Patil et al., 2013). These iridoids have numerous therapeutic uses like antihepatotoxic, choleretic, hypolipidemic, antiinflammatory, antispasmodic (Tiwari et al., 2012; Sultan et al., 2016). The dried extracts from the plant has a cure for liver disorders, fever, jaundice and allergies (Baruah et al., 1998). The herbal preparation of the plant plays a major role in antidiabetic and anticancerous activity (Pradhan 2011; Kumar \& Ramesh 2014; Mallick et al., 2015).

The over exploitation of the rhizomes of P. kurroa for the extraction of bioactive constituents along with the poor cultivation and small population size has depleted this species from its natural habitat (Verma et al., 2012). As a result, the plant is now listed as an endangered plant species in red data book by International Union for Conservation of Nature (IUCN). The conventional method of propagation using rhizomes and seeds restricts multiplication as seed germination is very poor in $P$. kurroa, so conservation using in vitro approaches is essential (Rawat et al., 2013).

It is necessary to develop a protocol for mass multiplication of this endangered high value medicinal plant so as to assure its conservation and the pharmaceutical demand. The present study was undertaken with the objective to improve the protocol for high frequency shoot multiplication and callus mediated somatic embryogenesis in $P$. kurroa under in vitro conditions.

\section{Materials and Methods}

\subsection{Plant material and surface sterilization}

The explants were excised from young and healthy growing parts of P. kurroa collected from high altitudes of Kishtwar area of Jammu and Kashmir. The plant parts were washed under running tap water so as to remove all the soil completely. Different explants like auxillary buds and internodal segments were excised from plant parts and were then collected in a beaker containing 2-3 drops of Tween 20 (Himedia) in distilled water. After $10 \mathrm{~min}$ the explants were washed thrice with distilled water.
The explants were then surface sterilized with $70 \%$ ethanol, mercuric chloride $\left(\mathrm{HgCl}_{2}\right)$, sodium hypochlorite and $1 \mathrm{ppm}$ Potassium permanganate $\left(\mathrm{KMnO}_{4}\right)$ in laminar air flow. A single or combinations of two or more sterilants were used for the surface sterilization of the explants.

\subsection{Culture medium and conditions}

MS (Murashige \& Skoog 1962) basal medium (Himedia) was used for the shoot establishment. The medium was supplemented with $3 \%(\mathrm{w} / \mathrm{v})$ sucrose and $0.8 \%(\mathrm{w} / \mathrm{v})$ agar. The $\mathrm{pH}$ of the medium was adjusted to 5.8 before autoclaving. MS medium with varying concentrations of growth hormones was prepared for shoot induction, multiplication and callus proliferation. Cultures were maintained at $25 \pm 2^{\circ} \mathrm{C}$ in $16 / 8 \mathrm{~h}$ light/dark cycle in tissue culture room. Subculturing was carried after 4-6 weeks interval. Care was taken to prevent any further contamination of subcultures from the microbes.

\subsection{Shoot proliferation and rooting}

Two weeks after the initial establishment of aseptic cultures, the shoot cultures thus obtained were further transferred for multiplication on to MS medium containing different combination and concentrations of BAP (Benzyl Amino Purine), Kn (Kinetin) and GA3 (Gibberellic Acid). Ten different MS medium combinations with growth regulators were tried for shoot multiplication (Table 1). For root induction, after 6 weeks the well developed in vitro grown shoots were separated singly and implanted on MS medium supplemented with different concentrations of IBA (Indole Butyric Acid) (Table 2).

\subsection{Callus induction and organogenesis}

Fully expanded young leaves of in vitro grown plants of $P$. kurroa were cut into small pieces using sterilized blade and then inoculated on MS medium containing 2,4 D (2, 4Dichlorophenoxy Acetic Acid) at different concentrations $(1.0 \mathrm{mg} / 1$ to $4.0 \mathrm{mg} / \mathrm{l})$ for callus induction and proliferation. The proliferated callus after six weeks was transferred to regeneration media containing $\mathrm{BAP}$, IAA and NAA (Napthalene Acetic Acid).

\subsection{Somatic embryogenesis and plant regeneration}

After eight weeks of culturing, the small pieces of friable and embryogenic callus were transferred to MS medium containing 2,4-D $(2.0,2.5,3.0 \mathrm{mg} / \mathrm{l})$ for induction of somatic embryos. After 4 weeks of subculturing, greenish yellow embryoids were observed. These pro embryoids were subcultured on same medium for maturation for next two weeks. Mature somatic embryos were transferred to regeneration MS medium containing BAP $(0.5,1.0,1.5,2.0 \mathrm{mg} / \mathrm{l})$ and GA3 (1.0mg/l). 
Table 1 Different concentrations and combinations of growth hormones used for shoot and root multiplication in P. kurroa.

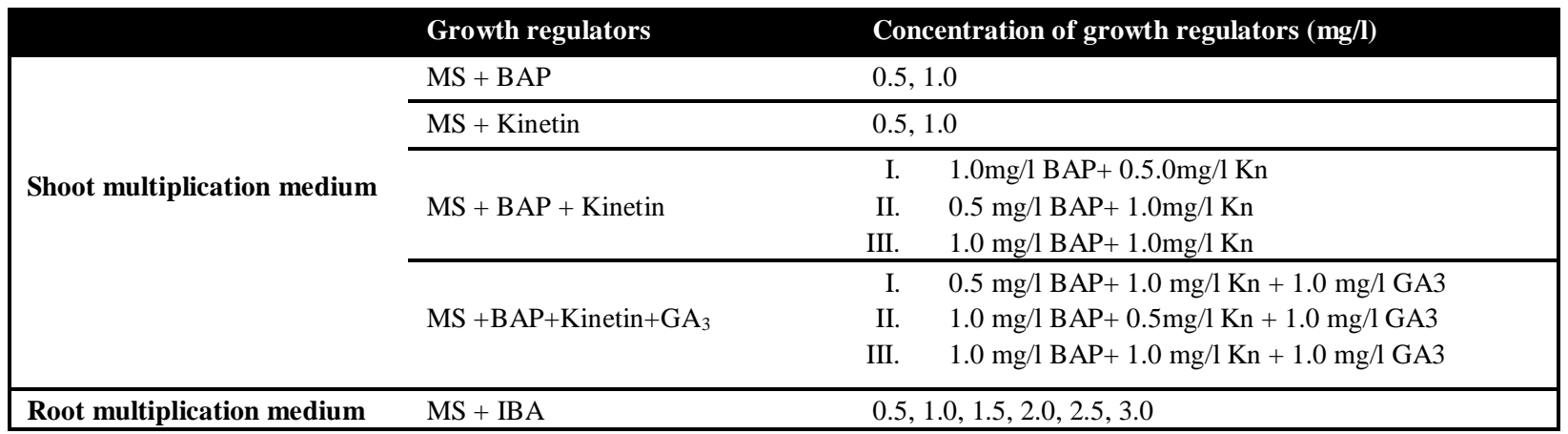

\section{Results and Discussion}

3.1 Surface Sterilization

The explants used in the present study were taken from the $P$. kurroa plant parts, collected from field. These were surface sterilized with sodium hypochlorite used at the concentration of $5.0 \%$ which resulted in $46.6 \%$ of uncontaminated explants Best sterilization treatment was $70 \%$ ethanol for $30 \mathrm{sec}$ followed by $\mathrm{HgCl}_{2}(0.1 \%)$ for 2 min and then $\mathrm{KMnO}_{4}(1 \mathrm{ppm})$ for 3 min resulting in $80.0 \%$ of uncontaminated explants. Similar results were also reported by Sen et al. (2014) where they observed that more than 3 min of surface sterilization with mercuric chloride is lethal to all of his tested varieties of A. aspera. Thus the herbaceous explants are always treated with low concentration of sterilants so that their soft tissues are not affected or damaged.

\subsection{Shoot multiplication}

The explants were established in MS basal medium after two weeks of inoculation (Figure 1a). The established shoots were transferred to shoot multiplication medium after four weeks. The best shoot multiplication was observed in MS medium supplemented with $1.0 \mathrm{mg} / \mathrm{l} \mathrm{BAP}, 0.5 \mathrm{mg} / \mathrm{Kn}$ and GA3 $(1.0 \mathrm{mg} / \mathrm{l})$. After six weeks of subculturing in shoot multiplication medium the plants regenerated into multiple shoots (Figure 1b). After six weeks the number of shoots per explant was counted and also their length was recorded.

The maximum percentage of shoot growth observed after six weeks was $85.63 \%$ with an average number of $8.7 \pm 0.18$ shoots per explant. The average shoot length was $5.92 \pm 0.29$ $\mathrm{cm}$. However, when the concentration of kinetin was increased to $1.0 \mathrm{mg} / \mathrm{l}$, the percentage shoot growth decreased to $80.21 \%$ and the average number of shoots was $7.8 \pm 0.15$ (Table 3). Venkatachalam et al. (2012) reported a high frequency (87.3\%) of shoot proliferation (6.2 shoots/explant) in MS medium supplemented with $2.0 \mathrm{mg} / \mathrm{l} \mathrm{BAP}$ in combination with $0.5 \mathrm{mg} / \mathrm{l}$ Kinetin in Gloriosa Superba while Patial et al. (2012) observed maximum number of shoots on MS medium supplemented with kinetin in P. kurroa.

In the present study, it was also observed that the shoots obtained on MS medium supplemented with BAP only, were healthy with long and thick leaves but the number of shoots was less whereas the number of shoots was more in MS media containing kinetin but the shoots were thin (Figure 2). Reduction in the number of shoots regenerated per explant with BAP as only growth regulator was also reported in A. squamosa (Nagori \& Purohit, 2004).

Table 2 Effect of different sterilants on the surface sterilization of explants.

\begin{tabular}{|llll|}
\hline S. No. & Treatments & Time duration & Percent survival of the explants \\
\hline $\mathbf{1}$ & $70 \%$ ethanol & $30-60$ sec. & Nil \\
\hline $\mathbf{2}$ & $\mathrm{KMnO}_{4}(1 \mathrm{ppm})$ & $3 \mathrm{~min}$ & $\mathrm{Nil}$ \\
\hline $\mathbf{3}$ & $70 \%$ ethanol $+\mathrm{HgCl}_{2}(0.05 \%)$ & $30 \mathrm{sec} .+2 \mathrm{~min}$. & 13.3 \\
\hline $\mathbf{4}$ & $70 \%$ ethanol $+\mathrm{HgCl}_{2}(0.1 \%)$ & $30 \mathrm{sec} .+2 \mathrm{~min}$. & 36.6 \\
\hline $\mathbf{5}$ & $70 \%$ ethanol $+\mathrm{HgCl}_{2}(0.2 \%)$ & $30 \mathrm{sec} .+4 \mathrm{~min}$. & 30.0 \\
\hline $\mathbf{6}$ & $70 \%$ ethanol $+\mathrm{HgCl}_{2}(0.5 \%)$ & $30 \mathrm{sec} .+2 \mathrm{~min}$. & 15.9 \\
\hline $\mathbf{7}$ & Sodium hypochlorite $(5 \% \mathrm{v} / \mathrm{v})$ & 5 min. & 46.6 \\
\hline $\mathbf{8}$ & Sodium hypochlorite $(10 \% \mathrm{v} / \mathrm{v})$ & $5 \mathrm{~min}$. & 20.0 \\
\hline $\mathbf{9}$ & $70 \%$ ethanol $+\mathrm{HgCl}_{2}(0.2 \%)+\mathrm{KMnO}_{4}(1 \mathrm{ppm})$ & $30 \mathrm{sec} .+2 \mathrm{~min}+3 \mathrm{~min}$ & 66.6 \\
\hline $\mathbf{1 0}$ & $70 \%$ ethanol $+\mathrm{HgCl}_{2}(0.1 \%)+\mathrm{KMnO}_{4}(1 \mathrm{ppm})$ & $30 \mathrm{sec} .+2 \mathrm{~min}+3 \mathrm{~min}$ & 80.0 \\
\hline
\end{tabular}




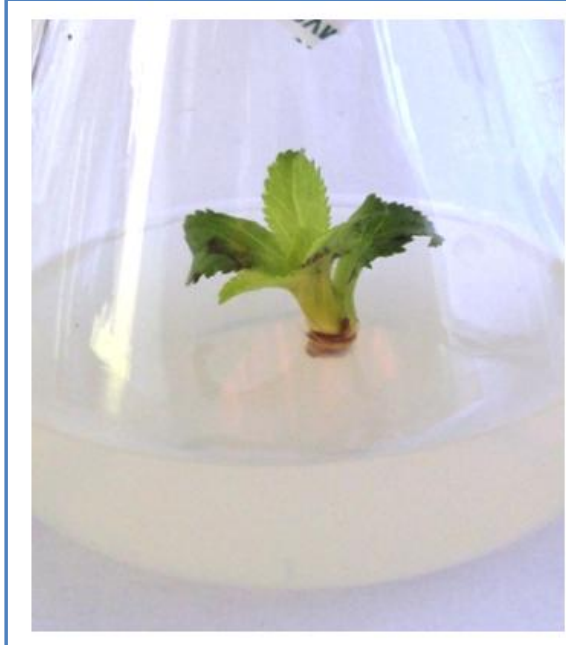

(A)

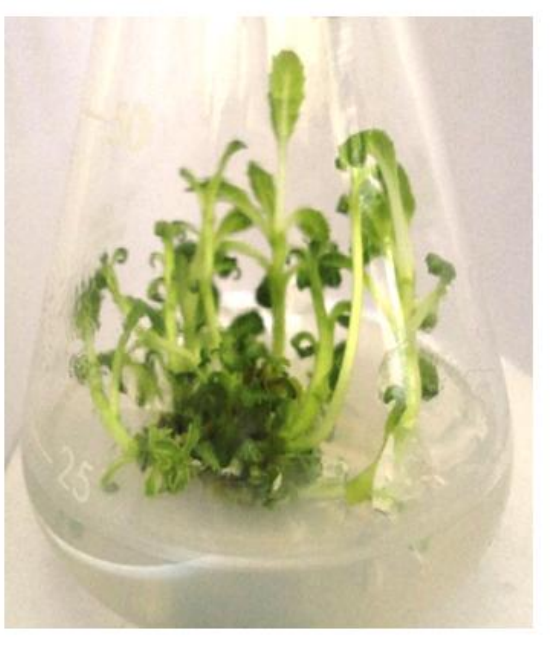

(B)

Figure 1 (A) Proliferation of leaves from auxiliary buds after two weeks MS medium (B) Shoot multiplication in MS medium with $\mathrm{BAP}, \mathrm{Kn}$ and $\mathrm{GA}_{3}$
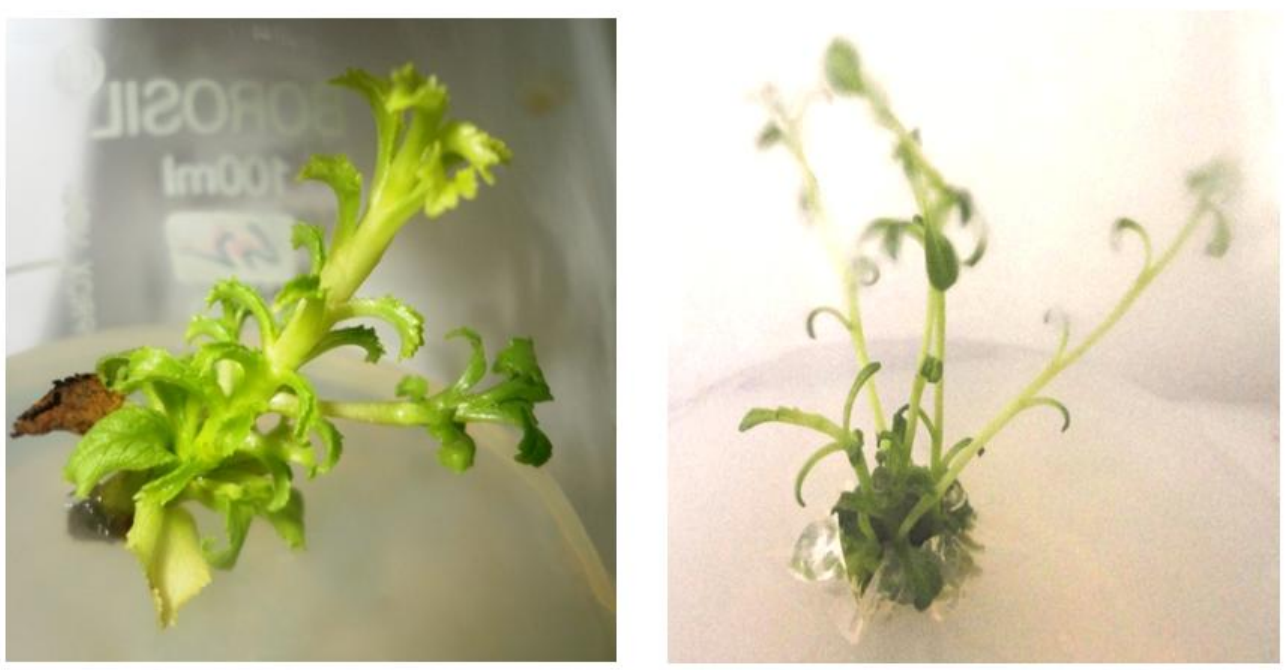

Figure 2 Effect of BAP and Kinetin in P. kurroa after 4 weeks of subculturing

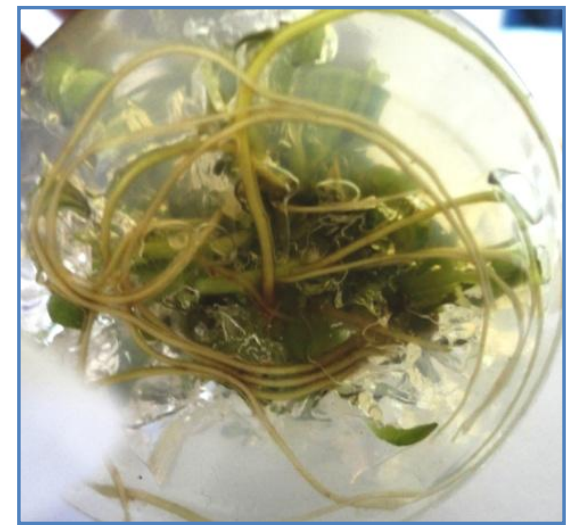

Figure 3 Root multiplication in MS medium with IBA after six weeks of sub culturing. 
Table 3 Effect of different concentrations of plant growth regulators on in vitro shoot multiplication in P. kurroa.

\begin{tabular}{|c|c|c|c|c|}
\hline $\begin{array}{l}\text { S.N } \\
0\end{array}$ & $\begin{array}{l}\text { Concentration of growth } \\
\text { regulators }(\mathrm{mg} / \mathrm{l})\end{array}$ & Percentage Shoot growth & $\begin{array}{c}\text { Average no. of shoots per } \\
\text { explant }\end{array}$ & $\begin{array}{c}\text { Average shoot length } \\
\text { (cms) }\end{array}$ \\
\hline 1 & $\mathrm{MS}+0.5 \mathrm{BAP}$ & 52.80 & $2.2 \pm 0.54$ & $2.17 \pm 0.58$ \\
\hline 2 & $\mathrm{MS}+1.0 \mathrm{BAP}$ & 66.20 & $2.7 \pm 0.38$ & $3.61 \pm 0.22$ \\
\hline 3 & $\mathrm{MS}+0.5 \mathrm{Kn}$ & 50.80 & $1.1 \pm 0.32$ & $1.21 \pm 0.37$ \\
\hline 4 & $\mathrm{MS}+1.0 \mathrm{Kn}$ & 59.06 & $1.9 \pm 0.51$ & $1.92 \pm 0.52$ \\
\hline 5 & $\mathrm{MS}+1.0 \mathrm{BAP}+0.5 \mathrm{Kn}$ & 68.60 & $6.8 \pm 0.21$ & $4.22 \pm 0.36$ \\
\hline 6 & $\mathrm{MS}+0.5 \mathrm{BAP}+1.0 \mathrm{Kn}$ & 63.41 & $5.7 \pm 0.25$ & $5.64 \pm 0.80$ \\
\hline 7 & $\mathrm{MS}+1.0 \mathrm{BAP}+1.0 \mathrm{Kn}$ & 72.49 & $4.2 \pm 0.51$ & $5.21 \pm 0.71$ \\
\hline 8 & $\begin{array}{c}\mathrm{MS}+1.0 \mathrm{BAP}+0.5 \mathrm{Kn}+1.0 \\
\mathrm{GA} 3\end{array}$ & 85.63 & $8.7 \pm 0.18$ & $5.92 \pm 0.29$ \\
\hline 9 & $\begin{array}{c}\mathrm{MS}+0.5 \mathrm{BAP}+1.0 \mathrm{Kn}+1.0 \\
\mathrm{GA} 3\end{array}$ & 76.54 & $8.2 \pm 0.22$ & $5.53 \pm 0.40$ \\
\hline 10 & $\begin{array}{c}\mathrm{MS}+1.0 \mathrm{BAP}+1.0 \mathrm{Kn}+1.0 \\
\mathrm{GA} 3\end{array}$ & 80.21 & $7.8 \pm 0.15$ & $5.22 \pm 0.69$ \\
\hline
\end{tabular}

*Data is from twenty shoots in three replicates and is represented as mean \pm SD

\subsection{In vitro rooting and hardening}

The addition of auxin in the rooting medium results in long length and higher number of roots as compared to hormone free medium. Development of healthy and long rootlets is helpful for the establishment of plantlets in the field. Direct, healthy root initiation and elongation was observed in $P$. kurroa after subculturing of elongated single shoots onto MS basal medium supplemented with different concentrations of IBA (Table 4; Figure 3).

Best rooting medium was MS medium supplemented with 2.5 $\mathrm{mg} / \mathrm{l}$ IBA resulting in $84.54 \%$ of root growth. The average number of roots per explant was $10.35 \pm 0.18$. The roots were long, healthy with numerous root hairs. As the concentration of IBA was increased to $3.0 \mathrm{mg} / \mathrm{l}$, the percent root growth and the average number of roots was decreased to $79.22 \%$ and $9.11 \pm 0.21$ respectively (Table 4). Similar effects of IBA were also observed during in vitro rooting in several other medicinal plant species (Baul et al., 2011; Praveena \& Veeresham 2014; Rahdari et al., 2014). The rooted plants were removed from flasks, washed carefully to remove agar and transferred to a potting mixture in plastic pots containing sand: soil (1:1). The plants were initially covered with jars in glass house for two weeks to maintain the humidity. About ninety percent rate of survival was obtained upon hardening.

\subsection{Callus induction}

Different concentrations of 2,4-D in MS medium resulted in callus formation from the leaf explants (Table 5). The callus was creamy white and friable in MS medium containing $2.0 \mathrm{mg} / \mathrm{l}$ and $3.0 \mathrm{mg} / 1$ 2,4-D (Figure 4). It was observed that the high concentration of 2,4-D (4.0mg/l) resulted in browning of explants with no callus formation. Similarly, Zuraida et al., (2015) has also reported that higher concentration of 2,4-D resulted in browning of the callus in Pelargonium radula.

Table 4 Effect of IBA concentration on in vitro rooting.

\begin{tabular}{|ccccl|} 
S. No. & $\begin{array}{c}\text { MS + Growth regulators } \\
(\mathbf{m g} / \mathbf{l})\end{array}$ & $\begin{array}{c}\text { \%age } \\
\text { rooting }\end{array}$ & $\begin{array}{c}\text { Average no. of roots per } \\
\text { explant }\end{array}$ & \multicolumn{1}{c|}{ Types of roots } \\
\hline 1. & MS +0.5 IBA & 35.40 & $1.23 \pm 0.27$ & Small thread like roots no root hairs. \\
\hline $\mathbf{2 .}$ & MS +1.0 IBA & 55.80 & $4.97 \pm 0.62$ & Thin, fragile roots with less root hair. \\
\hline $\mathbf{3 .}$ & MS +1.5 IBA & 68.56 & $7.14 \pm 0.34$ & Thin, fragile roots with root hairs. \\
\hline $\mathbf{4 .}$ & MS +2.0 IBA & 74.58 & $8.44 \pm 0.23$ & Thin, fragile roots with few root hairs \\
\hline $\mathbf{5 .}$ & MS +2.5 IBA & 84.54 & $10.35 \pm 0.18$ & $\begin{array}{l}\text { Long, well developed roots with numerous } \\
\text { root hairs. }\end{array}$ \\
\hline $\mathbf{6}$ & MS +3.0 IBA & 79.22 & $9.11 \pm 0.21$ & $\begin{array}{l}\text { Long, well developed roots with numerous } \\
\text { root hairs. }\end{array}$ \\
\hline
\end{tabular}

*Data is from fifteen plants in three replicates and is represented as mean $\pm \mathrm{SD}$ 


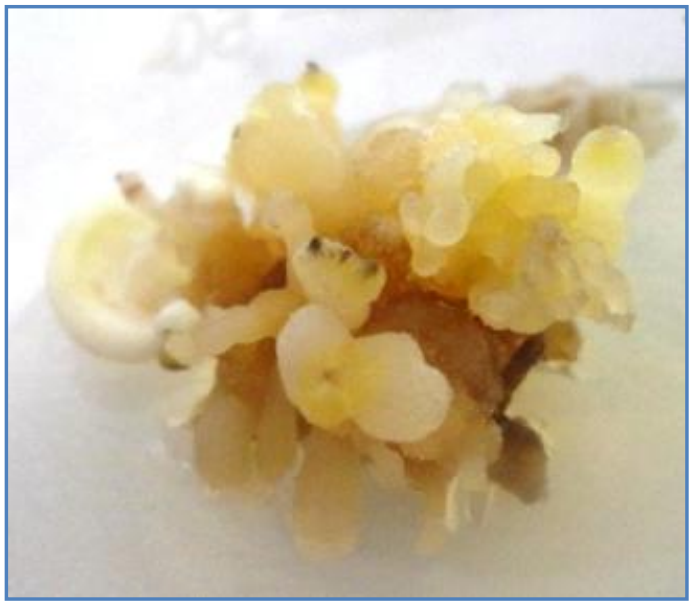

Figure 4 Callus proliferation in MS medium supplemented with 3.0mg/l 2,4-D.

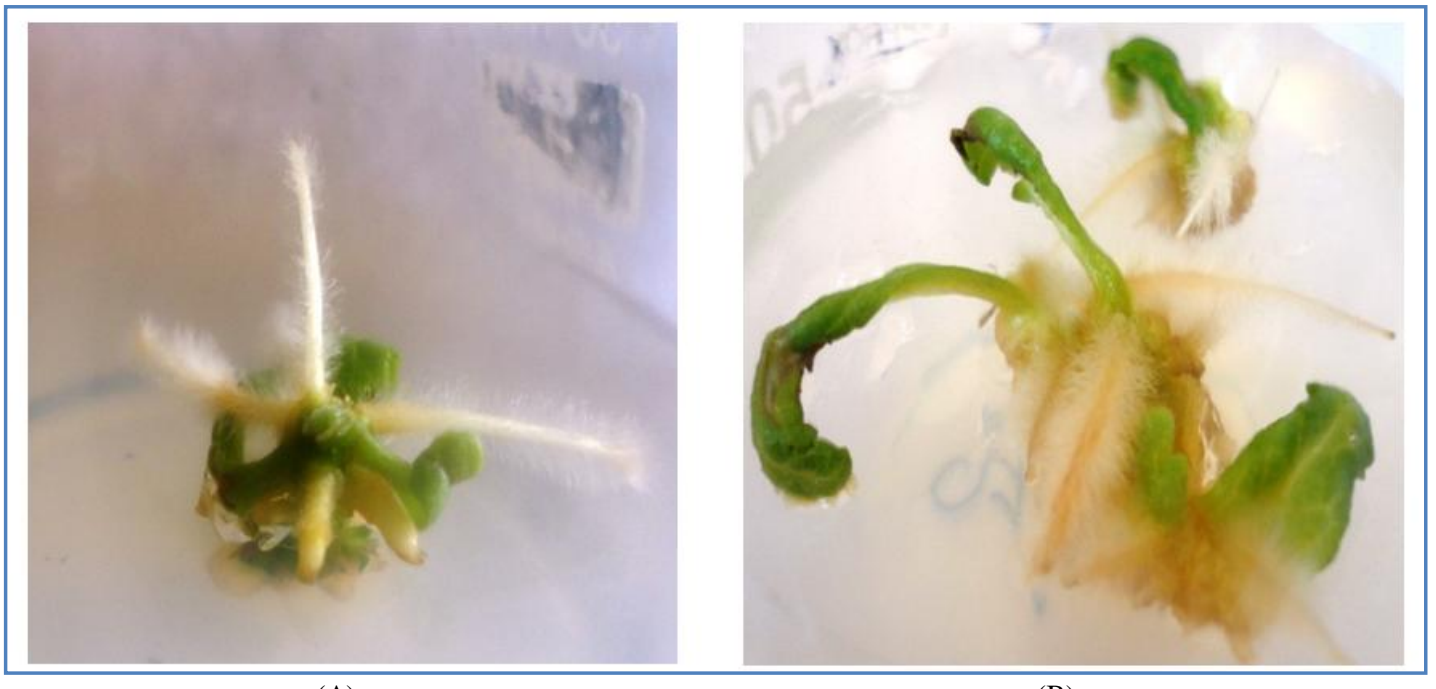

(A)

(B)

Figure 5 (A) Shoot and root induction from callus in MS media supplemented with 2,4-D, BAP and IAA (B) Root induction from leaf explants in MS medium supplemented with 2,4-D, IAA and NAA

After six weeks, MS medium supplemented with $2.5 \mathrm{mg} / 1$ 2,4$\mathrm{D}+1.0 \mathrm{mg} / \mathrm{l} \mathrm{BAP}+1.0 \mathrm{mg} / \mathrm{l} \mathrm{IAA}$ resulted in the formation of shoots along with the roots from the callus. When the proliferated callus was inoculated on MS medium containing $2.5 \mathrm{mg} / 12,4-\mathrm{D}+2.0 \mathrm{mg} / \mathrm{l} \mathrm{NAA}+0.5 \mathrm{mg} / \mathrm{IAA}$, then only root formation was observed (Figure $5 \mathrm{a}$ and $5 \mathrm{~b}$ ). The concentration of plant growth regulators needed to induce callus, varies from species to species and also depends on the source of explant (Ngomuo et al., 2014). It has been reported in many plants that 2,4-D is mostly used as auxin for callus induction (Junaid et al., 2007; Silveira et al., 2013) and addition of a low concentration of cytokinins in callus culture medium often enhances callus regeneration (Singh et al., 2009).

3.5 Somatic embryogenesis and shoot regeneration

Somatic embryogenesis has already been reported in many endangered plants for their in vitro conservation (Lee et al.,
2011; Kim et al., 2012; Giri et al., 2013; Barberini et al., 2016). In the present study, cytokinins were used as promoters for the induction of somatic embryos. The combination of both 2,4-D along with BAP and GA3 in MS medium significantly affected the number of embryo production. After four weeks, $2,4-\mathrm{D}$ at the concentration of $2.5 \mathrm{mg} / 1$ resulted in the formation of greenish yellow callus.

The callus when subcultured on the same medium resulted in the formation of many globular somatic embryos. Further subculturing resulted in the formation of globular, torpedo and heart shaped somatic embryos. Mature somatic embryos were transferred to regeneration medium containing BAP and GA3. The mature embryos turned green on MS medium supplemented with $1.0 \mathrm{mg} / \mathrm{l} \mathrm{BAP}$ and $1.0 \mathrm{mg} / \mathrm{l} \mathrm{GA} 3$ after a week and then after two weeks the shoots differentiated with one or two plumules was observed (Figure 6). 


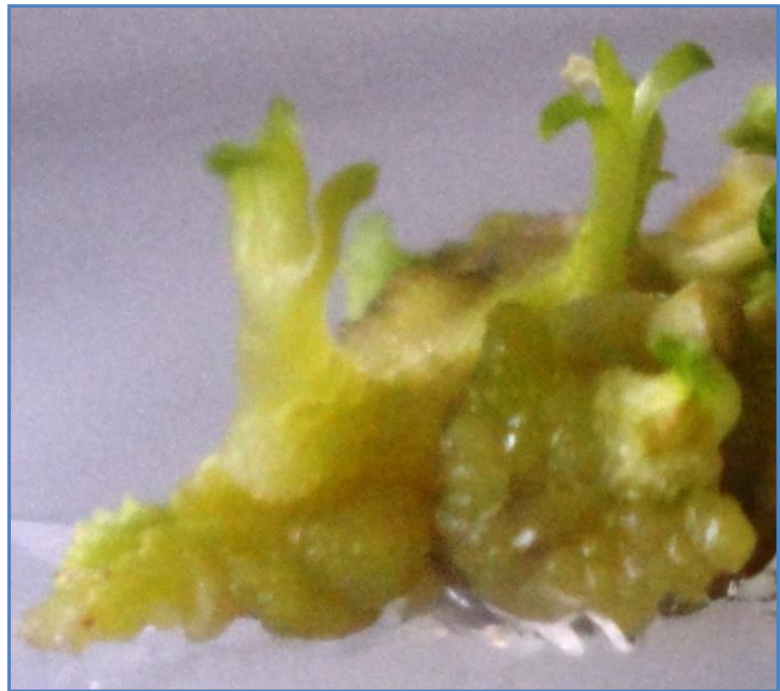

Figure 6 Shoot regeneration from somatic embryos in MS medium supplemented with 2,4-D, BAP and GA 3

Table 5 Effect of plant growth regulators on callus induction and regeneration after 6 weeks.

\begin{tabular}{|lllc|}
\hline S. No & MS+Growth hormones $(\mathrm{mg} / \mathrm{l})$ & Type of Response in P. kurroa & $\begin{array}{c}\text { Rate of callus } \\
\text { induction }\end{array}$ \\
\hline 1 & MS+1.0 2,4-D & No callus & -- \\
\hline 2 & MS+2.0 2,4-D & Creamy white, friable, small in size & + \\
\hline 3 & MS+3.0 2,4-D & Creamy white, friable, large in size & ++ \\
\hline 4 & MS+4.0 2,4-D & Browning of the explant & -- \\
\hline 5 & MS+2.5 2,4-D+ 1.0 BAP & Creamy white, friable callus, with shoots & +++ \\
\hline 6 & MS+2.5 2,4-D+1.0 BAP + 1.0 IAA & Creamy white, callus, with small shoots and roots & +++ \\
\hline 7 & MS+2.5 2,4-D+2.0 NAA +0.5 IAA & Creamy white callus , with large roots & +++ \\
\hline
\end{tabular}

---- Absent, + Less callus, ++ moderate growth, +++ Good growth rate

\section{Conclusions}

The in vitro techniques help in conservation and multiplication of medicinally important plants that are overexploited for their bioactive constituents. The present study has developed a protocol for mass multiplication and somatic embryogenesis in P. kurroa which will facilitate its rapid and large scale propagation. This study can facilitate the in vitro conservation of elite genotypes of this medicinally important endangered plant. Further the somatic embryogenesis opens a chance for the improvement of the plant through transgenic approach. Though further studies needs to be done for the improving the germination of somatic embryos and their further establishment in the green house.

\section{Conflicts of interest}

Authors would hereby like to declare that there is no conflict of interests that could possibly arise.

\section{Acknowledgements}

The authors are thankful to National Medicinal Plant Board (NMPB), New Delhi for their financial support. The authors are also thankful to School of Biotechnology, University of Jammu, Jammu for providing the basic facilities to carry out this research work.

\section{References}

Barberini S, Danti R, Lambard M (2016) Somatic plant regeneration from selected common cypress (Cupressus sempervirens L.) clones resistant to the bark canker disease. Plant Cell, Tissue and Organ Culture 124: 393-403. DOI 10.1007/s11240-015-0902-4

Baruah CC, Gupta PP, Nath A, Patnaik LG, Dhawan BN (1998) Anti-allergic and anti-anaphylactic activity of picroliv-a standardised iridoid glycoside fraction of Picrorhiza kurroa. Pharmacological Research 36: 487-92. DOI 10.1006/phrs.1998.0397 
Baul TK, Hossain MM, Mezbahuddin M, Mohiuddin M (2011) Vegetative propagation of Litsea monopetala , a wild tropical medicinal plant: Effects of indole-3-butyric acid (IBA) on stem cuttings. Journal of Forestry Research 22: 409-416. DOI 10.1007/s11676-011-0111-x.

Bodeker G, Klooster VT, Weisbord E (2014) Prunus africana (Hook.f.) Kalkman: The Overexploitation of a Medicinal Plant Species and Its Legal Context. Journal of Alternative and Complementary Medicine 20: $810-822$. DOI 10.1089/acm.2013.0459

Giri D, Tamta S (2013) Induction of Somatic Embryogenesis in Vulnerable Medicinal Plant Hedychium spicatum Buch-Ham ex Smith. Plant Tissue Culture and Biotechnology 23: 147155. DOI10.3329/ptcb.v23i2.17506

Junaid A, Mujib A, Bhat MA, Sharma MP, Šamaj J (2007) Somatic embryogenesis and plant regeneration in Catharanthus roseus. Biologia Plantarum 51: 641-646. DOI 10.1007/s10535-007-0136-3

Kim YJ, Lee OR, Kim KT, Yang DC (2012) High Frequency of Plant Regeneration through Cyclic Secondary Somatic Embryogenesis in Panax ginseng. Journal of Ginseng Research 36: 442-448. DOI: 10.5142/jgr.2012.36.4.442

Kumar HM, Ramesh C (2014) Anticancer activity of nano encapsulated formulation from the extracts of Picrorhiza kurroa against human cancer cell lines. Journal of Pharmacognosy and Phytochemistry 2: 182-185. DOI 10.1016/0006-2952(93)90364-3

Lee OR, Sathiyaraj G, Kim YJ, In JG, Kwon WS, Kim JH, Yang DC (2011) Defense genes induced by pathogens and abiotic stresses in Panax ginseng C.A. Meyer. Journal of Ginseng Research 35: 1-11. DOI 10.5142/jgr.2011.35.1.001

Mallick MN, Singh M, Parveen R, Khan W, Ahmad S, Najm MZ, Husain SA (2015) HPTLC Analysis of Bioactivity Guided Anticancer Enriched Fraction of Hydroalcoholic Extract of Picrorhiza kurroa. BioMed Research International 2015: 513875. DOI 10.1155/2015/513875

Mugula BB, Vries BJ, Bingi SW (2010) Mechanisms for sustainable use of biodiversity in and beyond natural ecosystems: a study on conservation and commercial production of Prunus africana in Uganda. International Journal of Biodiversity and Conservation 2: 180-185.

Murashige T, Skoog F (1962) A revised medium for rapid growth and bio-assays with tobacco tissue cultures. Physiologia Plantarum 15: 473-497. DOI 10.1111/j.13993054.1962.tb08052

Nagori R, Purohit SD (2004) Plantlet regeneration in Annona squamosa through direct shoot bud differentiation on hypocotyls segments. Scientia Horticultarae 99: 89-98. DOI 10.1079/IVP2005682

Ngomuo M, Emerald Mneney E, Ndakidemi PA (2014) The in vitro propagation techniques for producing banana using shoot tip cultures. American Journal of Plant Sciences 5: 1614-1622. DOI 10.4236/ajps.2014.511175

Patil AA, Sachin BS, Shinde DB, Wakte PS (2013) Supercritical $\mathrm{CO} 2$ assisted extraction and LC-MS identification of picroside I and picroside II from Picrorhiza kurroa. Phytochemical Analysis 24: 97-104. DOI 10.1002/pca.2383

Patial V, Devi K, Sharma M, Bhattacharya A, Ahuja PS (2012) Propagation of Picrorhiza kurroa Royle ex Benth: An important medicinal plant of Western Himalaya. Journal of Medicinal Plants Research 6: 4848-4860. DOI 10.5897/JMPR12.115

Pradhan S (2011) Antihyperglycemic effect of various medicinal plants of Sikkim Himalayas - A review. International Journal of Research in Phytochemistry \& Pharmacology 1: 124-130.

Praveena C, Veeresham C (2014) Multiple shoot regeneration and effect of sugars on growth and nitidine accumulation in shoot cultures of Toddalia asiatica. Pharmacognosy Magazine 10: S480-S486. DOI 10.4103/0973-1296.139777

Rahdari P, Khosroabadi M, Delfani K, Hoseini SM (2014) Effect of Different Concentration of Plant Hormones (IBA and NAA) on Rooting and Growth Factors in Root and Stem Cuttings of Cordyline Terminalis. Journal of Medical and Bioengineering 33: 190-194. DOI 10.12720/jomb.3.3.190-194

Rawat B, Rawat JM, Mishra S, Mishra NS (2013) Picrorhiza kurroa: current status and tissue culture based biotechnological interventions. Acta Physiologiae Plantarum 35: 1-12. DOI 10.1007/s11738-012-1069-9

Sen MK, Nasrin S, Rahman S, Jamal AHM (2014) In vitro callus induction and plantlet regeneration of Achyranthes aspera L, a high value medicinal plant. Asian Pacific Journal of Tropical Biomedicine 4: 40-46. DOI 0.1016/S22211691(14)60206-9.

Silveira DG, Lino LSM, Souza ADS, Souza FVD (2013) Somatic embryogenesis of Neoglaziovia variegata (Arruda) $\mathrm{Mez}$, an important source of fiber from native Brazilian bromeliads. Brazilian Archives of Biology and Technology 56: 547-555. DOI 10.1590/S1516-89132013000400004.

Singh P, Singh A, Shukla KA, Singh L, Pande V, Nailwal TK (2009) Somatic embryogenesis and in vitro regeneration of an endangered medicinal plant sarpgandha (Rauvolfia serpentina L.). Life Science Journal 6: 57-62. 
Sultan P, Jan A, Pervaiz Q (2016) Phytochemical studies for quantitative estimation of iridoid glycosides in Picrorhiza kurroa Royle. Botanical Studies An International Journal 57:7. DOI 10.1186/s40529-016-0121-2

Tiwari SS, Pandey MM, Srivastava S, Rawat AK (2012) TLC densitometric quantification of picrosides (picroside-I and picroside-II) in Picrorhiza kurroa and its substitute Picrorhiza scrophulariiflora and their antioxidant studies. Biomedical Chromatography 26: 61-68. DOI 10.1002/bmc.1626

Venkatachalam P, Ezhili N, Thiyagarajan M (2012) In vitro Shoot Multiplication of Gloriosa Superba L.- An Important
Anticancer Medicinal Herb. In: International Conference on Biotechnology, Biological and Biosystems Engineering, December 18-19, Phuket, pp. 246-249.

Verma P, Mathur AK, Jain SP, Mathur A (2012) In vitro Conservation of Twenty-Three Over exploited Medicinal Plants Belonging to the Indian Sub Continent. The Scientific World Journal 2012: 929650. DOI 10.1100/2012/929650

Zuraida AR , Mohd Shukri MA, Erny Sabrina MN, Nazreena OA (2015) Improvement of Regeneration of Pelargonium radula via Somatic Embryogenesis. British Biotechnology Journal 5: 166-173. DOI 10.9734/ BBJ/2015/15337 